\title{
ELEPHANTIASIS WITH PREGNANCY - GOOD MATERNAL AND PERINATAL OUTCOME
}

Jagrati Kiran Naagar ${ }^{1}$, Vrunda Joshi², Nilesh Dalal ${ }^{3}$, S. K. Rajoriya ${ }^{4}$

\section{HOW TO CITE THIS ARTICLE:}

Jagrati Kiran Naagar, Vrunda Joshi, Nilesh Dalal, S. K. Rajoriya. "Elephantiasis with Pregnancy - Good Maternal and Perinatal Outcome". Journal of Evolution of Medical and Dental Sciences 2014; Vol. 3, Issue 59,

November 06; Page: 13335-13337, DOI: 10.14260/jemds/2014/3776

\begin{abstract}
Elephantiasis had been described in India by Sushruta (600 BC) and in Persia by Rhazes and Anicenna. So this disease is as ancient as our history.Microfilaria was first demonstrated in human blood in Calcutta by Lewis who called it filarial sangunis hominis wuchheria bancrofti is distributive widely in the tropics and sub-tropics of Asia, Africa and south America.so the largest number of cases of Filariasis occur in India where over 300 million people live in endemic zones. It is estimated that at least 6 million attacks of acute filarial disease occur every year in India and that over 15 million peoples have chronic filarial disease. The endemic areas are mainly along the sea coast and along the banks of large rivers through infections occur virtually in all states except the north-west. Aprimigravida 25 year old patient was admitted in tili hospital labour room with history of Amenorrohea 9 month with history of elephantiasis of right leg since birth and complain of pain abdomen since morning at 7:40 am on 13/9/2012. By menstrual history her LMP was? December 2009 and by this LMP patient EDD was? September 2010.because of huge swelling of right leg normal delievery could not be possible so she was taken for LSCS, patient delivered a full term alive female baby of $2.8 \mathrm{~kg}$ weight on 13/9/2010 at 1:45 pm patient stood procedure well post-operative period was uneventfull. Stitches were removed on $8^{\text {th }}$ and $9^{\text {th }}$ day and patient and baby were well at the time of discharge. Filariasis can lead to sub-fertility but this is very rare case of huge elephantiasis with good maternal and faetal outcome.
\end{abstract}

KEYWORDS: Elephantiasis, LSCS.

INRTODUCTION: Elephantiasis is a disease that is characterised by thickning of skin and underlying tissues especially legs. Elephantiasis is a late manifestation of lymphatic filariasis, which apart from limbs may involve genitalia or breasts. Elephantiasis caused by lymphatic filariasis, is one of the most common cause of disability in world.

INCIDENCE: Among 120 million infected people in 83 countries, up to 16 million have lymphedema. In endemic countries approximately $10 \%$ of women can be affected with swellen limbs and $50 \%$ of mens suffering from mutilating genital disease.

PREVLANCE: Of 53 studies from Africa, South East Asia, the Indian Subcontinent and The Americas, 43 showed a lower mean prevalence of infection in females than in males. Prevalence is consistently lower in women of reproductive age and this is statistically significant in 16 of 32 studies classified by age and sex. Density of infection is also lower in the reproductive age but may be higher in children and in older women.

CAUSED BY: Lymphatic filariasis, transmitted by mosquitoes is the commonest cause of lymphedema in endemic countries. wuchharia bancrofti, brugiamalayi, loaloa are men pethogen. lymphedema. Microfilariae ingested by mosquitoes grow into infective larvae. 
These larvae entering humans after infected mosquito bites grow in the lymphatics to adult worms that cause damage to lymphatics resulting in dilatation of lymph vessels.

\section{CASE DISCUSSION:}

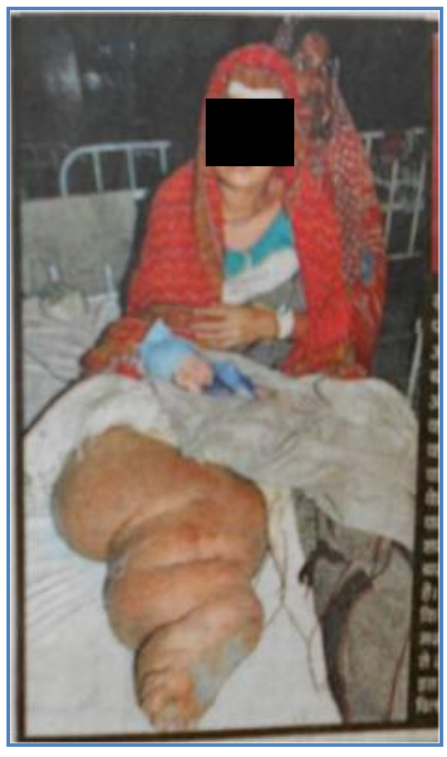

A patient Sharda 25 years old wife of Shri Babloo Lodhi residence of Heerapur Surkhi was admitted in Tili Dufrin hospital. Associated with Bundelkhand Medical College on 13/09/2010 at 7:40 am with complain of amenorrohea 9 months with history of Elephantiasis right leg since birth and complain of pain in lower abdomen since morning.

She is primigravida and her marital life is 2 years and by menstrual history her Lmp was? December 2009 and by this her EDD was? September 2010.

\section{ON EXAMINATION:}

\section{On general examination:}

GC is fair, afebrile,

Pulse regular 90 per minute,

Pallor 2+, BP 110/80 $\mathrm{mm}$ of $\mathrm{Hg}$,

Oedema $2+$.

Huge swelling ++ present on her right side of limb involving whole leg upto hipjoint since birth.

Elephantiasis ++ on her right side.

\section{SYSTEMIC EXAMINATION:}

lungs clear, CVS, $\mathrm{S}_{1}, \mathrm{~S}_{2} \mathrm{NAD}$.

On per Abdomen examination - Abdominal wall thickness ++ uterus full term, vertex down, fetal heart sound + regular 140 per minute.

On local examination vulval oedema ++ .

On pervagional examination - cervical os 3-4 cm dilated, 50-60 percent effaced, vertex at -1 station, membrane present early bag forming both side wall convergent. 


\section{INVESTIGATIONS:}

Routine investigations were sent. Antibiotic was given. Physician reference was taken and is prepared for Lscs.

On investigations $\mathrm{Hb}-8 \mathrm{~g} \%$, bleeding time 2 minute 26 seconds, clotting time 4 minute 19 seconds, blood group $\mathrm{AB}+$, urine Routine Microscopic examination NAD.

Peripheral blood smear was taken during night for micro fileria which was negative.

\section{DURING OPERATION:}

LSCS was done.

During LSCS foot end was raised because of large surface area of right Leg to prevent anesthetic complications.

Patient delivered a full term alive female baby of $2.8 \mathrm{~kg}$ weight by vertex on 13/09/2010 at 1:40pm. 1unit blood was given intra operatively.

Patient stood procedure well.

\section{POST OPERATIVE:}

Post op period was uneventful. Stitches were removed on 8th and 9th day stitch line healthy.

Patient was discharged on 9th day.

Medical openion taken on discharge.

Mother and baby both are healthy at the time of discharge.

\section{REFERENCES:}

1. Journal of Anaesthesiology clinical pharmacology karuna Sharma, sapna gupta, udita navthe, sunanda gupta.

2. Huge filarial elephantiasis vulvae in Nigerian women with sub-fertility (Archgynae and obs2008) pubmed.

3. Text book of medical parasitology C. K. JAYRAM PANIKER $6^{\text {th }}$ edition.

\section{AUTHORS:}

1. Jagrati Kiran Naagar

2. Vrunda Joshi

3. Nilesh Dalal

4. S. K. Rajoriya

\section{PARTICULARS OF CONTRIBUTORS:}

1. Assistant Professor, Department of Obstetrics and Gynaecology, Bundelkhand Medical College, Sagar.

2. Professor and HOD, Department of Obstetrics and Gynaecology, Bundelkhand Medical College, Sagar.

3. Associate Professor, Department of Obstetrics and Gynaecology, Bundelkhand Medical College, Sagar.
4. Senior Resident, Department of Anaesthesia, Bundelkhand Medical College, Sagar.

\section{NAME ADDRESS EMAIL ID OF THE CORRESPONDING AUTHOR:}

Dr. Jagrati Kiran Naagar, Block No. 2, Flat No. 12,

Bundelkhand Medical College,

Tili, Sagar - 470002, M. P.

E-mail: dr.jagratikirannaagar@gmail.com

Date of Submission: 04/08/2013.

Date of Peer Review: 04/09/2013.

Date of Acceptance: 19/02/2014.

Date of Publishing: 06/11/2014. 